\title{
Traditional method of fish treatment, microbial count and palatability studies on spoiled fish
}

\author{
Ambiga Paneer Selvam ${ }^{1}$, Seri Intan $\underline{\text { Mokhtar }}^{1}$, Nur Ain $\underline{\text { Abd Aziz }}{ }^{1}$ and Seri Bunian Mokhtar ${ }^{2}$ \\ ${ }^{1}$ University Malaysia Kelantan, Jeli Campus, Kelantan, Malaysia. \\ ${ }^{2}$ Politeknik Sultan Azlan Shah, Tanjung Malim, Perak, Malaysia. \\ Email: intan@umk.edu.my
}

Received 17 August 2012; Received in revised form 8 October 2012; Accepted 8 October 2012

\begin{abstract}
Aims: To evaluate the microbial count and palatability acceptance of spoiled fish after treatment with traditionally used natural solution.

Methodology and results: To compare microbial count of spoiled fish before and after treatment with natural solution practiced by local people in Malaysia, $10 \mathrm{~g}$ of spoiled fish was respectively rinsed with $100 \mathrm{~mL}$ of $0.1 \%$ of natural solution such as Averrhoa bilimbi extract, rice rinsed water, rice vinegar, Citrus aurantifolia extract, salt, flour, and Tamarindus indica extract. Flesh of fish rinsed with rice vinegar was found to be able to reduce microbial count (CFU/mL $\left.=0.37 \times 10^{7}\right)$ more than 4.5 times when compared to spoiled fish $\left(\mathrm{CFU} / \mathrm{mL}=1.67 \times 10^{7}\right)$. Spoiled fish that was treated with rice vinegar was prepared into a cutlet and fried. The cutlet was subjected to palatability acceptance study by a group of residents in Palm Court Condominium, Brickfields, Kuala Lumpur. The palatability study from the Cronbach alpha shown that the taste have the reliability of 0.802 , the aroma has the reliability of 0.888 , colour with the reliability of 0.772 , texture or mouth feel have reliability of 0.840 and physical structure of the cutlet is 0.829 .

Conclusion, significance and impact of study: Treatment of spoiled fish using rice vinegar as practice by local people traditionally shown a significant reduction in microbial count and the vinegar-treated fish could be developed into a product that is safe and acceptable by the consumer.
\end{abstract}

Keywords: spoiled fish, traditional treatment, rice vinegar

\section{INTRODUCTION}

Fish is one of the most important protein sources in human nutrition. Each year, tones of fish have been landed (FAO, 2007). Among these fish, there are also 6.82 million metrics tonnes of discarded or spoiled fish in Asia countries (Kelleher, 2005). According to Kelleher (2005), discarded or spoiled fish is the fish that before was taken to the shore or brought to the surface of vessel and are then thrown back to the sea which is already dead or dying or going to die. The fish is discarded for various reasons such as wrong species of fish, not preferable sized fish, fish that is not preferred sex, damaged fish, inedible or poisonous fish, spoilage of fish occurs rapidly, quotas or high grading, season, gear, prohibited fishing area and lack of space on the boat (Clucas, 1997).

According to Matthew and Hammond (1999), discarding has becoming a very serious issue currently especially to the health and environment. Discarded or spoiled fish producing pungent smell usually is caused by microbial action. Spoilt fish has indigenous bacteria and also enteric bacteria which could cause food borne illness in human. Indigenous bacteria are Clostridium botulinum, Vibrio spp., Aeromonas hydrophila and enteric bacteria are Salmonella spp., Shigella spp., Escherichia coli, and Staphylococcus aureus (Lyhs, 2009). Moreover, since fish becoming more expensive, discarded or spoiled fish which was thrown back to the sea before are now being converted into edible food products such as Fish Protein Concentrates (FPC), Silage, Collagen Chitin, Chitosan, Fish pickles, Sausages, Surimi, Fish balls and etc (Raffi, 2011).

In Malaysia, it is a normal traditional practice in each household to rinse fish using natural solution to remove the smell (Hanieliza, 2010a; b). Many natural solutions such as rice water, tamarind extract, vinegar, salt, lime extract, flour are being used daily. However, there is no study done on the effectiveness of these solution in removing the smell and spoilage of fish by microbes. Therefore, we would like to explore the possibility of providing simple solution to reduce the number of microbes that causing spoilage of and convert the treated fish into a product that is acceptable by the society.

\section{MATERIALS AND METHODS}

\section{Preparing fish flesh for treatment}

For this research, Nemipterus japonicus or its local name ikan kerisi, one of the most popular fish in the East Coast of Malaysia and also highly perishable was used. The fish was obtained from the local market around Jeli, Kelantan area. To 
stimulate the spoiling process for the fish, fresh fish was bought and kept at room temperature for $24 \mathrm{~h}$. After $24 \mathrm{~h}$ the fish internal organs was removed and the flesh was used for treatment.

\section{Treatment of fish flesh}

For control, $10 \mathrm{~g}$ of spoiled flesh and fresh flesh were rinsed with sterile water (Berkel, 2004). For treatment, $10 \mathrm{~g}$ of spoiled flesh was rinsed in $100 \mathrm{~mL}$ of $0.1 \%$ fresh and clean Averrhoa bilimbi extract, rice vinegar, Citrus aurantifolia extract, salt, flour, rice rinsed water and extract of Tamarindus indica for $1 \mathrm{~min}$.

\section{Microbial count for treated fish flesh}

For microbial test, $10 \mathrm{~g}$ sample of control and treated flesh was blended with $100 \mathrm{~mL} 0.1 \%$ peptone water to achieve the final volume of $250 \mathrm{~mL}$ until a homogeneous suspension was obtained. $\mathrm{pH}$ of flesh suspension was adjusted with $\mathrm{NaOH}$ or $\mathrm{HCL}$ to be between around 5.5 to 7.6. The flesh suspension was centrifuged at $1,200 \mathrm{rpm}$ for $30 \mathrm{~min}$ to concentrate the pellet. $1.0 \mathrm{~mL}$ of the supernatant was collected and serially diluted to $10^{-5}$. Approximately $0.1 \mathrm{~mL}$ of each dilution was transferred into nutrient agar and spread using hockey stick. For microbial growth, the agar plate were inverted and incubated at $37^{\circ} \mathrm{C}$ for $48 \mathrm{~h}$ (Downes and Ito, 2001).

\section{Preparation of cutlet}

For preparation of fish cutlet, $100 \mathrm{~g}$ of potato was boiled in 1.5 $L$ water with $1 / 2$ teaspoon of turmeric powder and 1 teaspoon of salt until the potato cooked well. At the same time, fish was filleted to remove bone and smashed. Other ingredients such as onion, ginger, pepper powder, were added into the smashed ingredients. Then all of the ingredients were mixed well until fine dough was obtained. The dough were divided into small pieces and then dipped into egg and bread crumbs before deep frying in cooking oil.

\section{Cutlet microbial test}

Cutlet microbial test was conducted as done for microbial test for fish flesh.

\section{Cutlet protein test}

Protein content of the fish cutlet was determined using Kjeldahl (Rhee, 2001). The method is divided into three parts which are digestion, distillation and titration.

\section{Cutlet palatability}

Cutlet palatability was done through distributing questionnaires to respondent. The sensory attributes that were tested are texture or mouth feel, smell/odour/aroma, taste, physical structure and colour (Luning and Marcelis, 2009). Each item and it's decription used in the fish cutlet palatability test is shown in Table 1.

\section{RESULTS}

\section{Fish treatment}

Flesh of fish rinsed with rice vinegar has less microbial count $\left(\mathrm{CFU} / \mathrm{mL}=0.37 \times 10^{7}\right)$ compared to the fresh fish $(\mathrm{CFU} / \mathrm{mL}=$ $\left.0.50 \times 10^{7}\right)$ and spoiled fish $\left(\mathrm{CFU} / \mathrm{mL}=1.67 \times 10^{7}\right)$. Most of other treatments (Figure 1 ) were able to reduce the count of microbes compared to the spoiled fish $\left(\mathrm{CFU} / \mathrm{mL}=1.67 \times 10^{7}\right)$ but still more that the fresh fish $\left(\mathrm{CFU} / \mathrm{mL}=0.50 \times 10^{7}\right)$, flesh of fish rinsed with rice water has the microbial count of $\mathrm{CFU} / \mathrm{mL}=0.85 \times 10^{7}$, followed by fish rinsed with flour $\left(\mathrm{CFU} / \mathrm{mL}=0.99 \times 10^{7}\right)$, Averrhoa bilimbi extract $(\mathrm{CFU} / \mathrm{mL}=$ $\left.1.05 \times 10^{7}\right)$, salt $\left(\mathrm{CFU} / \mathrm{mL}=1.3 \times 10^{7}\right)$. However, flesh of fish rinsed with Citrus aurantifolia extract $\left(\mathrm{CFU} / \mathrm{mL}=2.06 \times 10^{7}\right)$ and Tamarindus indica extract $\left(\mathrm{CFU} / \mathrm{mL}=3.08 \times 10^{7}\right)$ have microbial count more than the spoiled fish. Rice vinegar has the ability to reduce a significant number of the microbes comparing with other treatments given to the fish. This is maybe due to the acidity nature of the vinegar.

Table 1: Item and its description that was used for the fish cutlet palatability test.

\begin{tabular}{|c|c|}
\hline Item & Description \\
\hline Taste 1 & Do you like fish? \\
\hline Taste 2 & $\begin{array}{l}\text { Have you ever eaten products made } \\
\text { from fish? }\end{array}$ \\
\hline Taste 3 & $\begin{array}{l}\text { Do you like food made from fish } \\
\text { product? }\end{array}$ \\
\hline Taste 4 & Do you like cutlets? \\
\hline Taste 5 & Do you like fish cutlet? \\
\hline Taste 6 & Do you like the taste of the fish cutlet? \\
\hline Aroma 1 & Do you like the aroma of the cutlet? \\
\hline Aroma 2 & $\begin{array}{l}\text { Does the aroma induce you to consume } \\
\text { it? }\end{array}$ \\
\hline Aroma 3 & Is the cutlet aroma suitable for it? \\
\hline Colour 1 & $\begin{array}{l}\text { Does the colour of the cutlet induces you } \\
\text { to consume it? }\end{array}$ \\
\hline Colour 2 & Is the colour of the cutlet suitable? \\
\hline $\begin{array}{l}\text { Texture/mouth } \\
\text { feel } 1\end{array}$ & Do you like the texture of the cutlet? \\
\hline $\begin{array}{l}\text { Texture/mouth } \\
\text { feel } 2\end{array}$ & Is the cutlet juicy? Do you like it? \\
\hline $\begin{array}{l}\text { Texture/mouth } \\
\text { feel } 3\end{array}$ & $\begin{array}{l}\text { Is the cutlet is smooth and no any large } \\
\text { bits of any ingredients? }\end{array}$ \\
\hline $\begin{array}{l}\text { Texture/mouth } \\
\text { feel } 4\end{array}$ & $\begin{array}{l}\text { Are the ingredients of the cutlet well } \\
\text { blended? }\end{array}$ \\
\hline $\begin{array}{l}\text { Physical } \\
\text { Structure } 1\end{array}$ & Is the cutlet soft? \\
\hline $\begin{array}{l}\text { Physical } \\
\text { Structure } 2\end{array}$ & $\begin{array}{l}\text { Is the physical structure of the cutlet } \\
\text { smooth and no any large bits of } \\
\text { ingredients? }\end{array}$ \\
\hline
\end{tabular}


Mal. J. Microbiol. Vol 9(2) 2013, pp. 135-139

\section{$\begin{array}{ll}\text { Physical } & \text { Is the shape of the cutlet suitable? }\end{array}$}

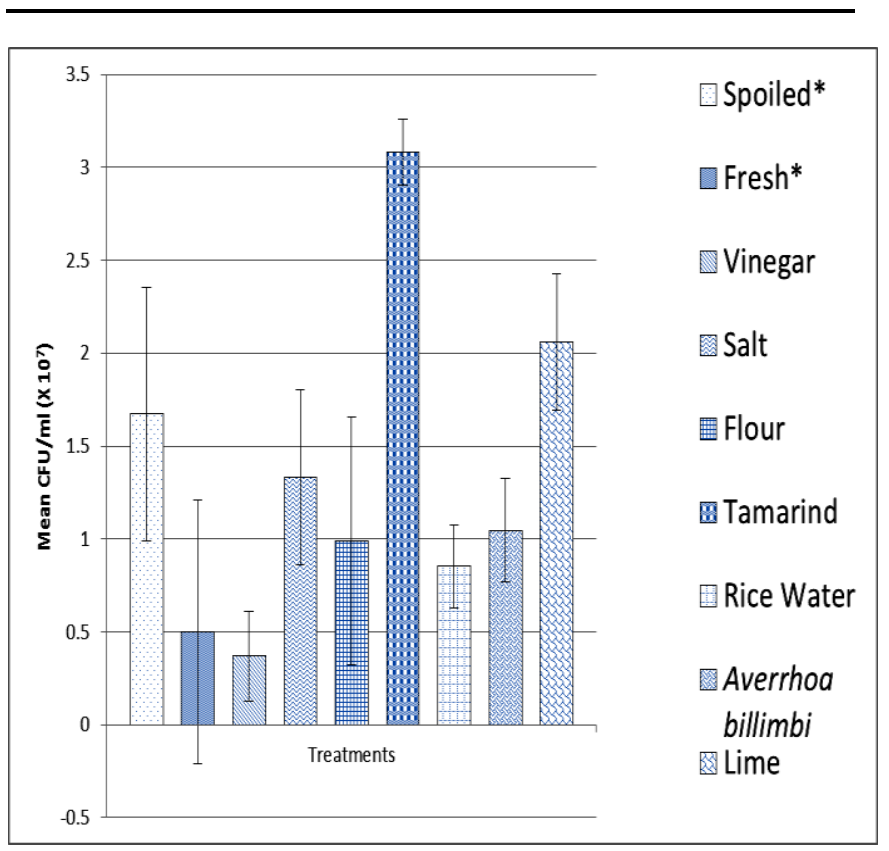

Figure 1: Microbial count of fresh, spoiled and treated fish flesh grown on nutrient agar at $37^{\circ} \mathrm{C}$ for $48 \mathrm{~h}$.

\section{Cutlet microbial test}

The mean of colony forming unit (Table 2) for spoiled fish cutlet $\left(2.30 \times 10^{6} \mathrm{CFU} / \mathrm{mL}\right)$ is not significantly $(p>0.05)$ lower than fresh fish cutlet $\left(3.34 \times 10^{6} \mathrm{CFU} / \mathrm{mL}\right)$.

Table 2: The microbial count (CFU/mL) of fish cutlet prepared from flesh of fish treated with rice vinegar and fist cutlet prepared with fresh fish.

\begin{tabular}{|c|c|c|c|c|}
\hline \multicolumn{2}{|c|}{ Fish Cutlet } & \multirow{2}{*}{$\frac{\mathrm{CFU} / \mathrm{mL}}{2.30 \times 10^{6}}$} & \multirow{2}{*}{$\begin{array}{c}\begin{array}{c}\text { Std. } \\
\text { Deviation }\end{array} \\
.64031\end{array}$} & \multirow{2}{*}{$\begin{array}{l}\text { t-test value } \\
\mathrm{P}=0.056\end{array}$} \\
\hline Pair 1 & Treated & & & \\
\hline & Fresh & $3.34 \times 10^{6}$ & .92751 & \\
\hline
\end{tabular}

\section{Cutlet protein test}

Protein content was analyzed for the spoiled fish and fresh fish cutlet using the Kjedhal method. The protein content of spoiled fish cutlet is $14.28 \%$ while for the fresh fish was $10.06 \%$ as shown in Table 3.

Table 3: Protein contents of the fish cutlet prepared from fresh and spoiled fish were determined using Kjeldahl (Rhee, 2001).

\begin{tabular}{ll}
\hline Flesh of fish $(\mathrm{g})$ & Protein content $(\%)$ \\
\hline
\end{tabular}

\begin{tabular}{ll}
\hline Spoiled fish & 14.28 \\
Fresh fish & 10.06 \\
\hline
\end{tabular}

\section{Cutlet palatability}

\section{Reliability}

All variables tested ie. fish cutlet's taste, aroma, colour, texture/mouth feel and physical structure all have Cronbach alpha value is between 0.7 and 0.9 . The Cronbach alpha for taste is 0.802 , aroma is 0.888 , colour is 0.772 , texture/mouth feel is 0.840 and for physical structure is 0.829 as shown in Table 4.

Table 4: Cronbach alpha reliability test result for items used as variables in the palatability test of the fish cutlet.

\begin{tabular}{lcc}
\hline Variables & Number of items & Cronbach alpha \\
\hline Taste & 6 & 0.802 \\
Aroma & 3 & 0.888 \\
Colour & 2 & 0.772 \\
Texture/mouth feel & 4 & 0.840 \\
Physical Structure & 3 & 0.829 \\
\hline
\end{tabular}

\section{Respondent's profile}

Approximately 50 questionnaires were distributed for the palatability test of the fish cutlet produced from the ricevinegar treated fish. From Table 5, there were 22 male (44\%) and 28 female (56\%) respondents for the test. The respondents mostly were from the age range of $13-20(24 \%)$. The least respondent is those from the aged 5-12 years old $(6.0 \%)$.

Table 5: Respondent's demographic profile of the rice vinegar treated fish cutlet palatability test.

\begin{tabular}{cccc}
\hline Background & Frequency (no) & $\begin{array}{c}\text { Percentage } \\
(\%)\end{array}$ \\
\hline Gender: & & \\
- & Male & 22 & 44 \\
- & Female & 28 & 56 \\
Age & & & \\
- & $5-12$ & 3 & 6.0 \\
- & $13-20$ & 12 & 24.0 \\
- & $21-30$ & 7 & 14.0 \\
- & $31-40$ & 10 & 20.0 \\
- & $41-50$ & 8 & 16.0 \\
- & $>50$ & 10 & 20.0 \\
Race & & & \\
- & Malay & & 8.0 \\
- & Indian & 4 & 66.0 \\
- & Chinese & 13 & 26.0
\end{tabular}


Mal. J. Microbiol. Vol 9(2) 2013, pp. 135-139

Religion

$\begin{array}{llcc}\text { - } & \text { Islam } & 6 & 12.0 \\ \text { - } & \text { Hindu } & 24 & 48.0 \\ \text { - } & \text { Buddha } & 10 & 20.0 \\ \text { - } & \text { Others } & 10 & 20.0\end{array}$

The majority of the respondents' races are Indians (66.0\%) followed by Chinese $(26.0 \%)$ and least was the Malays with percentage of $8.0 \%$. The respondents' religion were mostly Hindu (48.0\%), 10\% were Buddhist, $12 \%$ were Muslim and $20 \%$ were other religion.

\section{Descriptive analysis}

As shown in Table 6 the respondents likes the colour of the cutlet the most $(M=4.70)$. The score other the other elements were all above mean value of 4 . This is considered as overall good score for the fish cutlet.

Table 6: Descriptive analysis of the rice vinegar treated fish cutlet palatability test.

\begin{tabular}{lcccc}
\hline & N & Mean & $\begin{array}{c}\text { Overall } \\
\text { Mean }\end{array}$ & $\begin{array}{c}\text { Std. } \\
\text { Deviation }\end{array}$ \\
\hline Taste 1 & 50 & 4.26 & & \\
Taste 2 & 50 & 4.90 & & \\
Taste 3 & 50 & 4.36 & 4.46 & 0.22607 \\
Taste 4 & 50 & 4.36 & & \\
Taste 5 & 50 & 4.42 & & \\
Taste 6 & 50 & 4.44 & & \\
Aroma 1 & 50 & 4.10 & & \\
Aroma 2 & 50 & 4.06 & 4.13 & 0.09452 \\
Aroma 3 & 50 & 4.24 & & \\
Colour 1 & 50 & 4.64 & 4.70 & 0.08485 \\
Colour 2 & 50 & 4.76 & & \\
Texture 1 & 50 & 4.38 & & \\
Texture 2 & 50 & 4.16 & 4.32 & 0.10504 \\
Texture 3 & 50 & 4.34 & & \\
Texture 4 & 50 & 4.38 & & \\
PhyStruct 1 & 50 & 4.38 & & \\
PhyStruct 2 & 50 & 4.48 & 4.45 & 0.06429 \\
PhyStruct 3 & 50 & 4.50 & & \\
Valid N (listwise) & 50 & & & \\
\hline
\end{tabular}

\section{DISCUSSION}

Flesh of fish rinsed with rice vinegar has significantly less microbial count compared to the fresh fish and spoiled fish. Most of other treatments were able to reduce the count of microbes compared to the spoiled fish but still more that the fresh fish. However, flesh of fish rinsed with Citrus aurantifolia and Tamarindus indica extracts have microbial count more than the spoiled fish. Rice vinegar might have the ability to reduced microbial count due to present of acetic acid (Bell, 2002).
From the t-test conducted for fish cutlet for fresh and spoiled fish, 2 tailed value showed $p=0.056$. According to Schloesser (2000), the critical $P$ level at $p=0.05$ (5\%). Therefore, we can conclude that there is a statistically no significant difference between the mean of discarded fish cutlet and fresh fish cutlet. The microbial count in both discarded and fresh fish have no significant difference and therefore, the discarded fish cutlet is considered safe for consumption. Maximum recommended bacterial counts for marginally acceptable quality fish product is $10^{7} \mathrm{CFU} / \mathrm{g}$ (Silva, 2002). Therefore, the cutlet could be marketed as frozen food in the market since the microbial count of the cutlet made from discarded fish is $2.30 \times 10^{6} \mathrm{CFU} / \mathrm{g}$ (Note: $\mathrm{CFU} / \mathrm{g}=$ $\mathrm{CFU} / \mathrm{mL})$.

For the palatability analysis, after factor loading was carried out, most of the variables showed an acceptable range of reliability. Basically 0.7 or more reliability coefficients are considered adequate (Leech et al., 2005). According to Mokhtar et al. (2011), the reliability index of $0.90-1.00$ is very high, $0.70-0.89$ is high, $0.30-0.69$ is moderate and $0.00-0.30$ is low. Table 4 shows the reliability test for the survey conducted. We can conclude that all of the instruments from the questionnaire result have high reliability since the Cronbach alpha has the variable value above 0.7 .

The protein content for the spoiled fish is higher may be because the vinegar acidity that was used to wash the spoiled fish affects the protein content of the cutlet. According to Silva (2002), the protein content in lean fish has an average of protein content of $15 \%$ to $20 \%$. The protein content also varies with the species of fish. The percentage of protein content for the cutlet as shown in Table 3 is at acceptable level as frozen food product when comparing the protein content of fish ball as reported by Huda et al. (2010) which ranged between $7.54-9.89 \%$. According to Nurnadia (2011), the fish used in this research, $N$. japonicas, with local name 'ikan kerisi' has the protein content of $18.17 \pm 1.36 \%$. The protein content in this cutlet maybe lower than the original fresh fish because some ingredients such as potato, onion and ginger may have affect the protein content of the cutlet. The cutlet is subjected to high temperature which could cause the protein in the fish to degrade. This may also be the reason of the less protein content when comparing to the normal fish (Silva, 2002). According to Labconco (2012), the result for protein test may be different from expected due to uneven digestion, sample problem or even the acidity or salt of the sample used.

\section{CONCLUSION}

From the present research, a product from spoiled fish was able to be produced for human consumption. The microbial test conducted shows that the spoiled fish cutlets $(\mathrm{CFU} / \mathrm{mL}=$ $2.30 \times 10^{6}$ ) have almost same microbial count with the fresh fish cutlet $\left(\mathrm{CFU} / \mathrm{mL}=3.34 \times 10^{6}\right)$. Rice vinegar $(\mathrm{CFU} / \mathrm{mL}=$ $0.37 \times 10^{7}$ ) has the ability to reduce most of microbes in the spoiled fish compared to the other treatments using Averrhoa bilimbi, Citrus aurantifolia extract, salt, flour, rice rinsed water, and Tamarindus indica extract. The cutlet made from the spoiled fish has attracted the respondents for the organoleptic testing using questionnaire. Most of the respondents like the colour of the cutlet. From the Cronbach alpha result, all of the 
value is above 0.7 which is at satisfactory level. Therefore, spoiled fish can be used for human consumption after being treated with rice vinegar and turned into process product such as cutlet. This would avoid wastage of the spoiled fish where some places in the world the spoiled or discarded fish are thrown back into the sea.

\section{ACKNOWLEDGEMENTS}

The author would like to acknowledge Universiti Malaysia Kelantan for providing the grant to conduct this research under the university's short term grant scheme.

\section{REFERENCES}

Bell, K. L. (2002). Holistic Aromatherapy for Animals. Findhorn Press, Scotland. 107-127.

Berkel, B. M., Boogaard, B. and Heijnen, C. (2004). Agrodok 12: Preservation of fish and meat. Agromisa Foundation, Wageningen. pp. 16-22.

Clucas, I. (1997). A study of the options for utilization of bycatch and discards from Marine Capture Fisheries. Rome: FAO Fisheries Department.
Access on August 17 , 2011 http://www.fao.org/docrep/W6602E/w6602E04.htm.

Downes, F. P. and Ito, K. (2001). Compendium of methods for the microbiological examination of foods. In: Halophilic and Osmophilic Microorganisms. Downes, F. P. and Ito, K. (eds.). American Public Health Association, Washington,DC. pp. 189.

FAO. (2007). The State of World Fisheries and Aquaculture 2006 . In: Trash or Treasure? Low-value/trash Fish from Marine Fisheries in the Asia-Pacific Region. FAO Fisheries and Aquaculture Department, Rome, Italy. pp. 115-120.

Hanieliza, C (2010a). Senangnya memasak ikan. PTS Publications \& Distributors SDN.BHD. Kuala Lumpur. 11.

Hanieliza, C (2010b). Senangnya memasak ayam. PTS Publications \& Distributors SDN.BHD. Kuala Lumpur. 27.

Huda, N., Shen, Y., Huey, Y., and Dewi, R. (2010). Ingredients, proximate composition, colour and textural properties of commercial Malaysian fish balls. Pakistan Journal of Nutrition 9(12), 1183-1186.

Kelleher, K. (2005). Discards in the world's marine fisheries. Food and Agriculture Organization of the United Nations, Rome. pp. 17-53.

Labconco. (2012). A guide to Kjeldhal Nitrogen Determination Methods and Apparatus. Retrived from www.expotechusa.com/catalogs/labconco/pdf/KJELDA HLguide.PDF. Access on March 152012
Leech, N., Barrett, K. and Morgan, G. (2005). SPSS for intermediate statistics. In: Severeal Measures of Reliability. Lawrence Erbaum Associates Publishers, New Jersey, London. pp. 63-76.

Luning, P. A. and Marcelis, W. (2009). Food Quality Management: Technological and managerial principales and practices. Wageningen Academic Publishers. Netherlands. pp. $\mathbf{5 0 .}$

Lyhs, U. (2009). Fishery products quality, safety and authenticity. In: Microbiological Methods. Rehbein, $\mathrm{H}$, and Oehlenschläger, J. (eds.). Wiley-Blackwell, Oxford. pp. 318-338.

Matthews, E. and Hammond, A. (1999). Critical Consumption Trends and Implications. World Resource Institute. pp. 51-64.

Mokhtar, S. B., Rahman, S., Nor, H., Mokhtar, S. I., Yusof, N. and Idris, R. (2011). Selection and Review of Measurement Item of Students' Learning Environment. International Conference on Management (ICM 2011) Proceeding, Malaysia. pp. 58-67.

Nurnadia, A., Azrina, A. and Amin, I. (2011). Proximate composition and energetic value of selected marine fish. International Food Research Journal, vol.18, pp 137-148.

Raffi, S. (2011). Bycatch Resource. Retrived from ocw.unu.edu/...and-health/...mangroves/Bycatchresource.pdf. Access on August 11, 2011

Rhee, K. C. (2001). Determination of Total Nitrogen. Current Protocols in Food Analytical Chemistry. B1.2.1-B1.2.9

Schloesser, N. (2000). Paired Samples T Test. Retrived from Wellesley: http://www.wellesley.edu/Psychology/Psych205/pairtte st.htmL. Access on September 10, 2011

Silva, L. V. (2002). Hazard Analysis Critical Control Point (HACCP), Microbial Safety, and Shelf Life of Smoked Blue Catfish (Ictalurus Furcatus). B.Sc. Thesis. Tashkent State University, Uzbekistan. 